\title{
IMPLEMENTING DIFFERENT TUBULAR FRAMINGS ON HIGH-RISE STRUCTURES AND OPTIMIZING THEIR COST AND DRIFT CONTROL WITH AN OPTIMUM COLUMN SPACING
}

\author{
Saadat MALIK ${ }^{1}$, Syed Ikram UL HAQ ${ }^{1}$, Safdar Abbas ZAIDI ${ }^{2, *}$, Ataullah MAHER ${ }^{2}$ \\ ${ }^{1}$ Student - Civil Engineering Department, Sir Syed University of Engineering \& Technology-Karachi, \\ Pakistan. \\ ${ }^{2}$ Faculty of Civil Engineering Department, Sir Syed University of Engineering \& Technology-Karachi, \\ Pakistan. \\ * corresponding author: sszaidi@ssuet.edu.pk.
}

\section{Abstract}

This paper presents the results of variation in column spacing of a tube in its outer periphery concerning structural drift and cost optimization. For high rise structures, tubular framing and outrigger braced frames are considered as the most appropriate solution economically. In recent past not must study has been focused on the tubular frame in its columns spacing and span length. In this research, a simple square plan structure has been considered with different heights of 30,40 , and 50 story buildings. Six different framing systems of the tubular structure have been developed with different column spacing in each and employed to each high-rise structure. Concrete strength and steel yield strength has been taken as a fixed value for every model. Several models were developed with these combinations and the drift and structural safety have been optimized by reducing the cross-section sizes in each system. Seismic analysis has been carried out to evaluate the effects of varying column spacing in each tube. The comparison of all the employed systems was carried out and cost analysis has been made. Observations have been taken from drift, base shear, and cost analysis of each framing system of the tube, and certain results were concluded for structures with different height.
\end{abstract}

\section{Keywords:}

Optimal column spacing;

Tube framing systems;

Cost analysis;

Drift control;

Base shear.

\section{Introduction}

Today it is almost impossible to imagine a major city without tall buildings. As the most important symbols of today's cities, tall buildings have become a source of faith in technology. As the height of buildings increases, the choice of the structural system decreases. For tall buildings, the outrigger braced frame system and tubular structural system were commonly used in the recent past. The tubular structural system was introduced in the 1960s by "Fazl-ur-Rahman Khan". It consists of closely spaced peripheral columns connected by deep spandrel beams*, which resist all lateral loads, and inside there are few columns that are used to take gravity loads. For High-Rise buildings, the lateral displacement of the building also known as "Sway" increases excessively. Larger crosssections of the structural members can be used to provide required stiffness to reduce sway but, the building will become more expensive and the weight of the building increases which makes it vulnerable to seismic forces. Moment resisting frames found to be failed under higher lateral loading so shear walls were induced to control the lateral sway but there is a certain height level at which this shear wall works efficiently. Keeping this problem in eyes several advanced framing systems of tube, outriggers, and bundled tubes were introduced in the $20^{\text {th }}$ century.

From the structural design point of view, tall (high-rise) buildings, because of their extraordinary height, show great sensitivity to wind and earthquake-induced lateral loads than low-rise buildings. 
Estimating those lateral loads which play an important role in the design of tall buildings is more difficult than estimating vertical loads. Earthquake loads increase according to the building weight, and wind loads increase according to the building height. The set of tall building structural systems has developed over time started with rigid frame systems, and with the addition of shear-frame, outrigger frame, and tube systems, it has made much taller buildings possible.

\section{Literature background}

The tube system was innovated in the early 1960s by the famous structural engineer Fazlur Rahman Khan who is considered the "father of tubular design" [1]. The tube system can be likened to a system in which a hollow box column is cantilevering from the ground, and so the building exterior exhibits a tubular behavior against lateral loads. [2, 3] have categorized the most optimal building system for concrete structures under the guidelines of Fazlur Rahman Khan and this can be shown in Fig. 1. [4] compared outrigger system with a tube as more versatile in terms of the aspects of structural design and architectural aesthetics. [5] has studied different systems of a framed tube, Hexa-grid, Diagrid, and braced tube to investigate the structural material consumption focusing on premium for height using steel as a structural material. [6] studied the effects of a diagrid framing system for tall skyscrapers with the complex architecture of twisted, tilted, and freeform towers.

Tubular structures including tube in the tube can be idealized as prismatic cantilever flexural shear beam with fixed at the lower end while energy methods may be used for determining natural frequencies of structures [7]. [8] has proposed a mathematical model for tubular structure with multiple internal tubes using the minimum potential energy methods in combination with the variational approach. [9] develops a simple methodology to investigate the free vibration of tall buildings using the tube in tube framing system based on the transfer matrix approach with the aid of FORTRAN to solve complex problems and thus provided simple solutions in design technology. In a parametric study conducted by [10], the building performance of 41 story structure was modeled with different parameters of cross-sections and moment frames and the effect of column depth on tube action has been declared as most prominent among all. [11] and [12] conducted the study to check the effects of column spacing on moment-resisting frames with 5 story and 11 story structures respectively. It is of utmost importance to check the optimal spacing effect of the column in a tube structure as not much importance has laid on this direction in past.

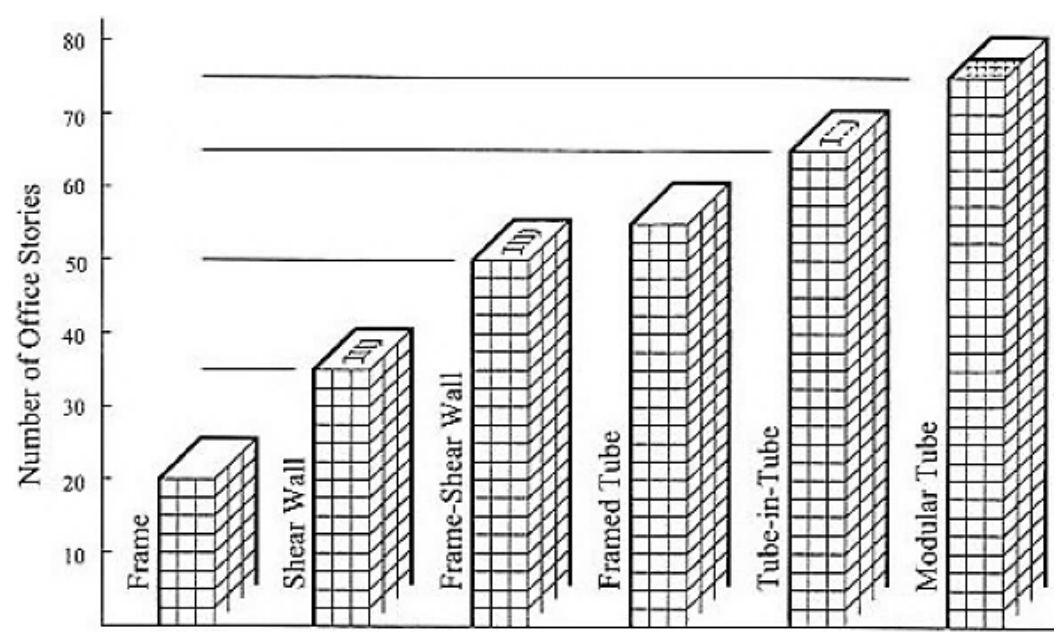

Fig. 1: Classification of building system for concrete by Fazlur Rahman Khan.

\section{Analysis}

In this research, for the simplicity of the analysis process, a squared bay plan of $23 \mathrm{~m} \times 23 \mathrm{~m}$ has been considered with different framings of the tube. Each plan has been developed with the varying spacing of columns in peripheral grids. To get a comprehensive idea of varying tube framings three different structured have been modeled with variation in their heights. Building heights have taken as 30 story, 40 story and 50 story structures with a typical story height of $3 \mathrm{~m}$ and each tube framing have been implemented on all three high-rise building structures. Tubular framings are designed in such a way that every frame includes only four internal columns to replace a core wall and most of the resistance has been induced by the outer tube only. Effects of different peripheral column 
spacing are compared on each building structure to investigate the efficiency of resisting lateral forces and this efficiency is measured in terms of structural safety, Drift control, and cost of the structure. Following structural systems have been developed in this context:

1. A system with peripheral column spacing of $2.3 \mathrm{~m}$ (CS 2.3).

2. A system with peripheral column spacing of $2.85 \mathrm{~m}$ (CS 2.85).

3. A system with peripheral column spacing of $3.8 \mathrm{~m}$ (CS 3.8).

4. A system with peripheral column spacing of $4.6 \mathrm{~m}$ (CS 4.6).

5. A system with peripheral column spacing of $7.6 \mathrm{~m}$ (CS 7.6).

6. A system with peripheral column spacing of $9.2 \mathrm{~m}$ (CS 9.2).

Live load of $2.4 \mathrm{kN} / \mathrm{m}^{2}$ and finishes loading, excluding self-weight, of $2.4 \mathrm{kN} / \mathrm{m}^{2}$ has been considered for each system. ETABS software has been utilized to model the effects of the abovementioned framing plans on different height structures. Building codes of ACI-318-08, ASCE-07, and UBC-97 [13-15] have been implemented for the design of building structures. Wind exposure of $B$ category i.e. building is supposed to be in urban and suburban areas with closely spaced obstructions; with a basic wind speed of $90 \mathrm{~m} / \mathrm{h}$ is considered here with concrete compressive strength of $27.6 \mathrm{MPa}$ and steel strength of $414 \mathrm{MPa}$. The seismic details considered in this research have been manipulated in Table 1. A very dense soil and soft rock type of ground have been considered for building a foundation with average shear wave velocity range of $360-760 \mathrm{~m} / \mathrm{s}$ and peak ground acceleration with the range of $0.16 \mathrm{~g}$ to $0.24 \mathrm{~g}$ have been applied for seismic loadings. An intermediate momentresisting frame type is assigned to the building frames for analytical purposes. The maximum allowable drifts are as under:

- Drift $(\max )=1 / 400$ for wind loading,

- Drift $(\max )=1 / 192$ for seismic loading.

Table 1: Seismic variables for building frames.

\begin{tabular}{|c|c|}
\hline Seismic zone & $2 \mathrm{~B}$ \\
\hline Soil orofile type & $\mathrm{Sc}$ \\
\hline Seismic coefficient, $\boldsymbol{C}_{\boldsymbol{a}}$ & 0.24 \\
\hline Seismic coefficient, $\boldsymbol{C}_{\boldsymbol{v}}$ & 0.32 \\
\hline Over strength factor & 5.5 (RC Frames) \\
\hline Building importance factor & 1 (Building framing) \\
\hline
\end{tabular}

The framing systems are shown below in Fig. 2. Here the slabs are designed using direct design method with manual calculation and structural drift is optimized by increasing the cross-section of structural elements. The column sizes are reducing after each five-story interval and all the columns are intended to design with minimum steel percentage of $1 \%$. It is also to be noted that due to symmetry of plan, torsion is well under the prescribed limit of codes. For cost analysis, the current construction market rates in Pakistan have been taken under consideration and converted into equivalent US Dollars i.e. one cubic foot of concrete costs 0.7 USD and one ton of steel costs 510 USD. For cost comparison and calculations, the only superstructure has been considered with structural frame only and slabs were excluded for cost analysis and similarly, foundations are also not taken into consideration.

\section{Analytical results}

\subsection{Analysis of $\mathbf{3 0}$ story structure}

Four tubular frames of CS 2.3, CS 4.6, CS 7.6 \& CS 9.2 have been analyzed for 30 story building. Two model frames were excluded here to save the analysis time since 30 story structure is not that high-rise hence a minimum column spacing of $2.3 \mathrm{~m}$ and an intermediate spacing of $4.6 \mathrm{~m}$ are compared with the normal span of column spacing. The results of the analysis are shown in Fig. 3.

Here optimization for CS 2.3 causes some issues as the sizes of members got reduced it causes structural failure, hence it results in thick cross-sections. CS 4.6 is relatively found stiffer and economical at this level. The base shear result is shown in Fig. 4. The base shear shows that CS 2.3 has less weight among all hence it will attract minimum earthquake forces, thus it is less vulnerable for 30 story structures. Table 2 shows the cross-section details of each framing employed in the analysis after optimizing drift and structural safety. 


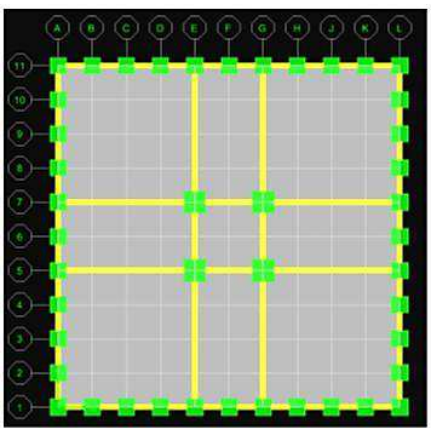

(CS 2.3)

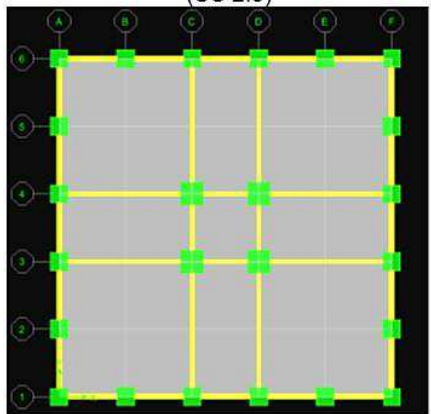

(CS 4.6)

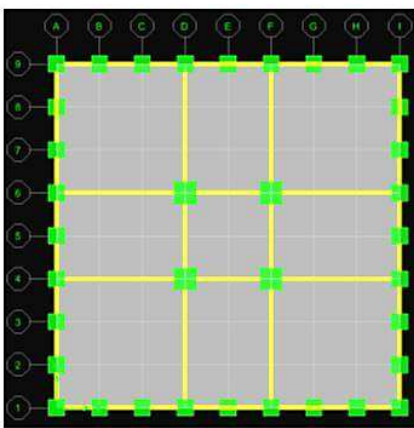

(CS 2.85)

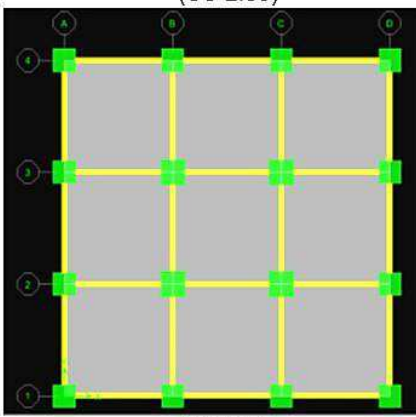

(CS 7.6)

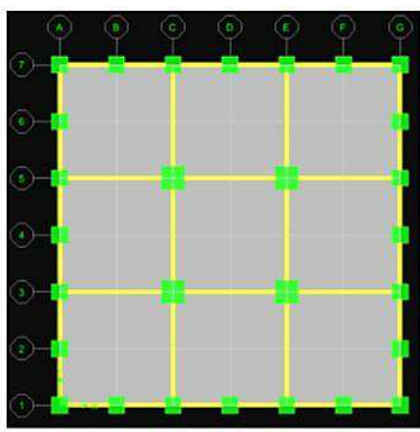

(CS 3.8)

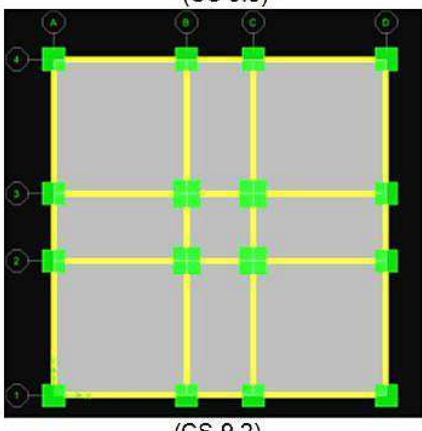

(CS 9.2)

Fig. 2: Different tubular framing plans implemented in analysis.

From the results of drift analysis, it can be seen that all four models have significant strength and response against wind loading while for seismic loading they are quite satisfactory as the sizes of the structural member were reduced to get minimum cost. The columns are designed in such a way that they result in a minimum steel percentage of 1 and cross-section size has been selected via trial and error technique. CS 2.3 \& CS 4.6 behaves a bit stiffer than the remaining two models against seismic load as seen in Fig. 3.
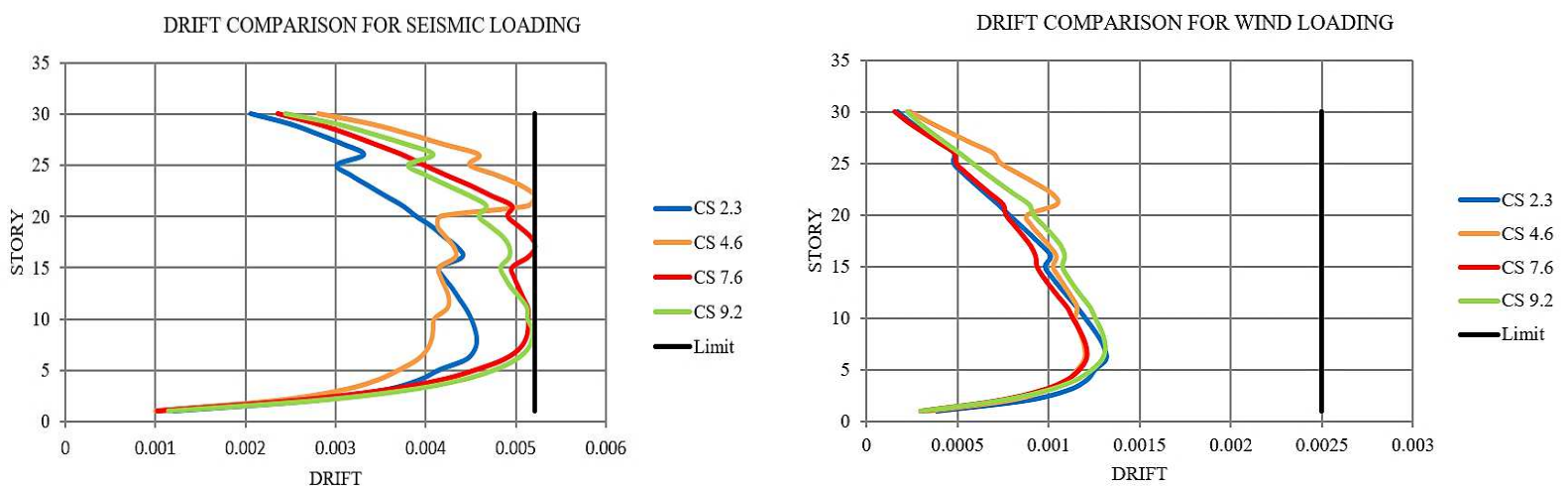

Fig. 3: Drifts comparison of the different tubular frame for 30 story structure for seismic loadings.

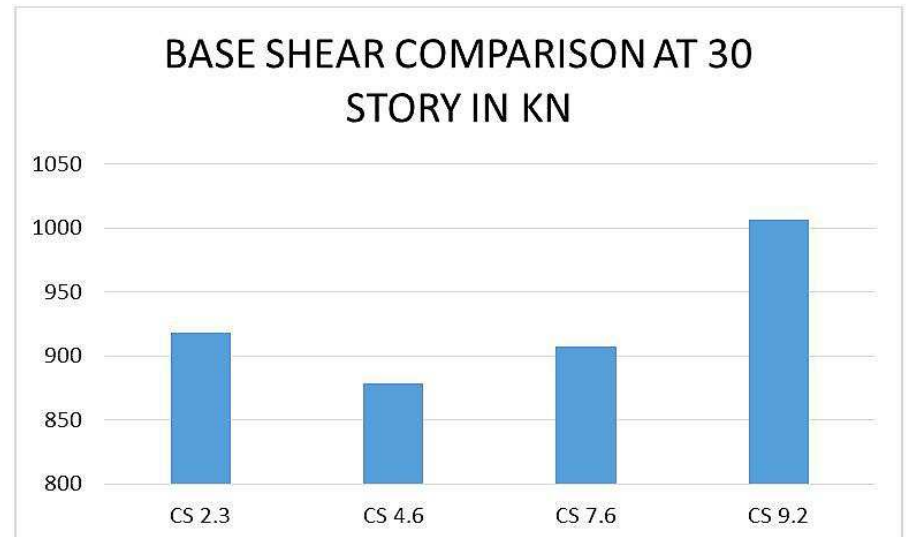

Fig. 4: Base shear results for 30 story building using different tube framings. 
Table 2: Cross-section details for all framing employed in 30 story structure (in $\mathrm{mm} \times \mathrm{mm}$ ).

\begin{tabular}{|c|c|c|c|c|c|}
\hline \multicolumn{2}{|c|}{ Element } & CS 2.3 & CS 4.6 & CS 7.6 & CS 9.2 \\
\hline $1^{\text {st }}$ to $5^{\text {th }}$ floor & $\begin{array}{l}\text { Periphery column } \\
\text { Inner column }\end{array}$ & $\begin{array}{c}610 \times 610 \\
1143 \times 1143\end{array}$ & $\begin{array}{c}762 \times 762 \\
1219 \times 1219\end{array}$ & $\begin{array}{l}1067 \times 1067 \\
1219 \times 1219\end{array}$ & $\begin{array}{l}1067 \times 1067 \\
1295 \times 1295\end{array}$ \\
\hline $6^{\text {th }}$ to $10^{\text {th }}$ floor & $\begin{array}{l}\text { Periphery column } \\
\text { Inner column }\end{array}$ & $\begin{array}{l}533 \times 533 \\
991 \times 991\end{array}$ & $\begin{array}{c}686 \times 686 \\
1143 \times 1143\end{array}$ & $\begin{array}{c}991 \times 991 \\
1143 \times 1143\end{array}$ & $\begin{array}{c}991 \times 991 \\
1219 \times 1219\end{array}$ \\
\hline $11^{\text {th }}$ to $15^{\text {th }}$ floor & $\begin{array}{l}\text { Periphery column } \\
\text { Inner column }\end{array}$ & $\begin{array}{l}533 \times 533 \\
914 \times 914 \\
\end{array}$ & $\begin{array}{l}610 \times 610 \\
991 \times 991 \\
\end{array}$ & $\begin{array}{l}914 \times 914 \\
991 \times 991 \\
\end{array}$ & $\begin{array}{c}914 \times 914 \\
1219 \times 1219 \\
\end{array}$ \\
\hline $16^{\text {th }}$ to $20^{\text {th }}$ floor & $\begin{array}{l}\text { Periphery column } \\
\text { Inner column }\end{array}$ & $\begin{array}{l}457 \times 457 \\
762 \times 762 \\
\end{array}$ & $\begin{array}{l}533 \times 533 \\
838 \times 838 \\
\end{array}$ & $\begin{array}{l}838 \times 838 \\
914 \times 914 \\
\end{array}$ & $\begin{array}{l}762 \times 762 \\
991 \times 991 \\
\end{array}$ \\
\hline $21^{\text {st }}$ to $25^{\text {th }}$ floor & $\begin{array}{l}\text { Periphery column } \\
\text { Inner column }\end{array}$ & $\begin{array}{l}457 \times 457 \\
686 \times 686\end{array}$ & $\begin{array}{l}457 \times 457 \\
686 \times 686\end{array}$ & $\begin{array}{l}686 \times 686 \\
762 \times 762\end{array}$ & $\begin{array}{l}610 \times 610 \\
838 \times 838\end{array}$ \\
\hline $26^{\text {th }}$ to $30^{\text {th }}$ floor & $\begin{array}{l}\text { Periphery column } \\
\text { Inner column }\end{array}$ & $\begin{array}{l}381 \times 381 \\
533 \times 533\end{array}$ & $\begin{array}{l}381 \times 381 \\
533 \times 533\end{array}$ & $\begin{array}{l}533 \times 533 \\
610 \times 610\end{array}$ & $\begin{array}{l}610 \times 610 \\
762 \times 762\end{array}$ \\
\hline Beam & $\begin{array}{l}\text { Periphery beam } \\
\text { Inner beam }\end{array}$ & $\begin{array}{l}254 \times 610 \\
203 \times 572\end{array}$ & $\begin{array}{l}203 \times 610 \\
203 \times 533\end{array}$ & $\begin{array}{l}254 \times 838 \\
254 \times 762\end{array}$ & $\begin{array}{l}381 \times 762 \\
381 \times 762\end{array}$ \\
\hline \multicolumn{2}{|c|}{ Slab } & 203 & 203 & 203 & 203 \\
\hline
\end{tabular}

The cost of the structural components has been calculated and shown in Fig. 5. It shows that $2.3 \mathrm{~m}$ spacing has much more stiffness than that of the required value for 30 stories thus resulting in higher cost while further increase in spacing of columns also yields in higher cost, therefore CS 4.6 is found to be most economical here.

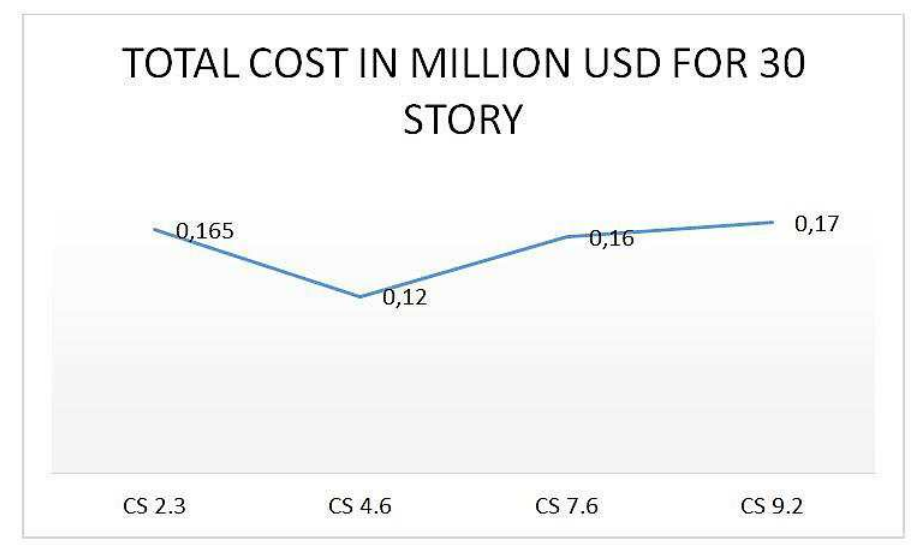

Fig. 5: Cost comparison for 30 story structure.

\subsection{Analysis of $\mathbf{4 0}$ story structure}

Here, the same four framing systems are utilized to check if it is still economical with CS 4.6. Surprisingly, for the 40 story structure, results remain the same among the discussed four framing types and CS 4.6 have been observed as most economical and enough optimized with drift control. The results of the analysis are given in Fig. 6 and Table 3.

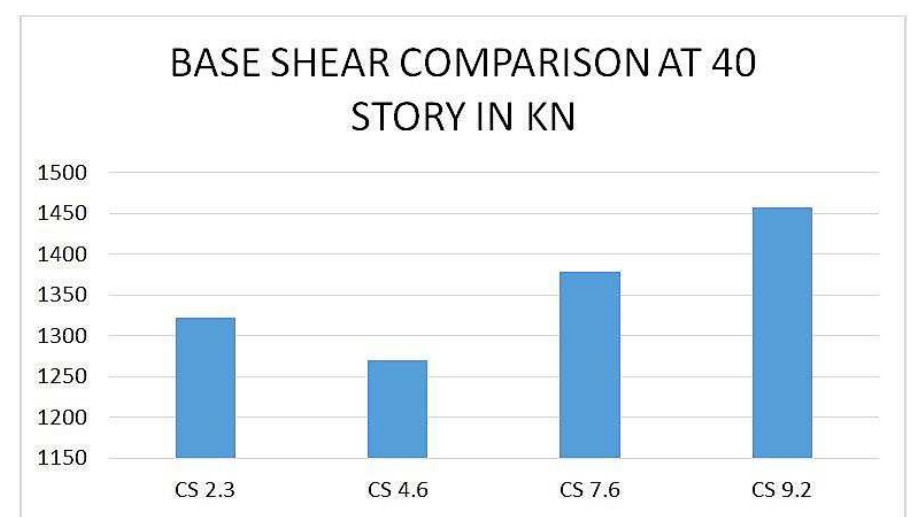

Fig. 6: Base shear results for 40 story building using different tube framings. 
In Fig. 7, the comparison of all four models against wind and seismic loadings is presented and seismic loads are found more critical then wind. Thus, optimization has been implemented for seismic loading, and sections are designed with the minimum steel ratios. The cost of the structural components has been calculated and shown in Fig. 8.
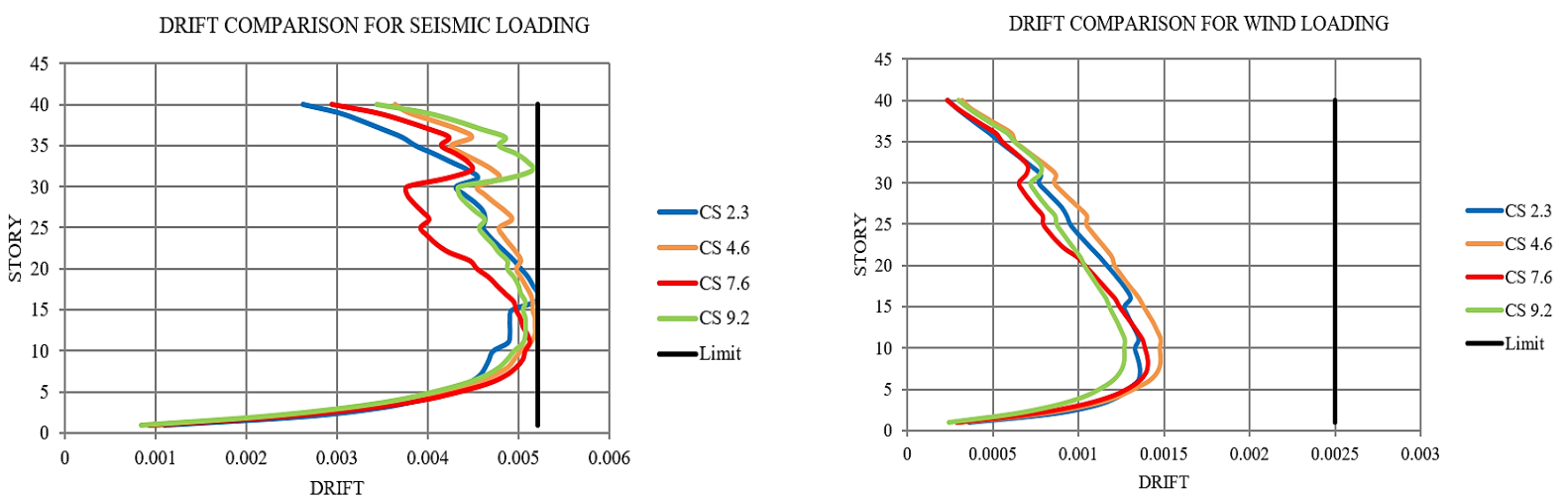

Fig. 7: Drifts comparison of the different tubular frame for 40 story structure.

Table 3: Cross-section details for all framing employed in 40 story structure (in $\mathrm{mm} \times \mathrm{mm}$ ).

\begin{tabular}{|c|c|c|c|c|c|}
\hline \multirow{2}{*}{\multicolumn{2}{|c|}{ Element }} & \multirow{3}{*}{$\begin{array}{c}\text { CS 2.3 } \\
762 \times 762 \\
1219 \times 1219\end{array}$} & \multirow{3}{*}{$\begin{array}{c}\text { CS } 4.6 \\
991 \times 991 \\
1372 \times 1372\end{array}$} & \multirow{3}{*}{$\begin{array}{c}\text { CS } 7.6 \\
1219 \times 1219 \\
1448 \times 1448\end{array}$} & \multirow{3}{*}{$\begin{array}{c}\text { CS 9.2 } \\
1295 \times 1295 \\
1524 \times 1524\end{array}$} \\
\hline & & & & & \\
\hline $1^{\text {st }}$ to $5^{\text {th }}$ floor & $\begin{array}{l}\text { Periphery column } \\
\text { Inner column }\end{array}$ & & & & \\
\hline $6^{\text {th }}$ to $10^{\text {th }}$ floor & $\begin{array}{l}\text { Periphery column } \\
\text { Inner column }\end{array}$ & $\begin{array}{c}6886 \times 686 \\
1143 \times 1143\end{array}$ & $\begin{array}{c}914 \times 914 \\
1295 \times 1295\end{array}$ & $\begin{array}{l}1143 \times 1143 \\
1372 \times 1372\end{array}$ & $\begin{array}{l}1219 \times 1219 \\
1448 \times 1448\end{array}$ \\
\hline $11^{\text {th }}$ to $15^{\text {th }}$ floor & $\begin{array}{l}\text { Periphery column } \\
\text { Inner column }\end{array}$ & $\begin{array}{c}610 \times 610 \\
1067 \times 1067\end{array}$ & $\begin{array}{c}762 \times 762 \\
1219 \times 1219\end{array}$ & $\begin{array}{l}1067 \times 1067 \\
1219 \times 1219\end{array}$ & $\begin{array}{l}1067 \times 1067 \\
1295 \times 1295\end{array}$ \\
\hline $16^{\text {th }}$ to $20^{\text {th }}$ floor & $\begin{array}{l}\text { Periphery column } \\
\text { Inner column }\end{array}$ & $\begin{array}{l}533 \times 533 \\
991 \times 991\end{array}$ & $\begin{array}{c}762 \times 762 \\
1067 \times 1067\end{array}$ & $\begin{array}{c}991 \times 991 \\
1143 \times 1143\end{array}$ & $\begin{array}{c}991 \times 991 \\
1219 \times 1219\end{array}$ \\
\hline $21^{\text {st }}$ to $25^{\text {th }}$ floor & $\begin{array}{l}\text { Periphery column } \\
\text { Inner column }\end{array}$ & $\begin{array}{l}533 \times 533 \\
914 \times 914\end{array}$ & $\begin{array}{l}686 \times 686 \\
991 \times 991\end{array}$ & $\begin{array}{c}838 \times 838 \\
1067 \times 1067\end{array}$ & $\begin{array}{c}914 \times 914 \\
1143 \times 1143\end{array}$ \\
\hline $26^{\text {th }}$ to $30^{\text {th }}$ floor & $\begin{array}{l}\text { Periphery column } \\
\text { Inner column }\end{array}$ & $\begin{array}{l}533 \times 533 \\
762 \times 762\end{array}$ & $\begin{array}{l}610 \times 610 \\
686 \times 686\end{array}$ & $\begin{array}{l}610 \times 610 \\
914 \times 914\end{array}$ & $\begin{array}{l}610 \times 610 \\
991 \times 991\end{array}$ \\
\hline $31^{\text {st }}$ to $35^{\text {th }}$ floor & $\begin{array}{l}\text { Periphery column } \\
\text { Inner column }\end{array}$ & $\begin{array}{l}457 \times 457 \\
686 \times 686\end{array}$ & $\begin{array}{l}533 \times 533 \\
686 \times 686\end{array}$ & $\begin{array}{l}533 \times 533 \\
914 \times 914\end{array}$ & $\begin{array}{l}533 \times 533 \\
914 \times 914\end{array}$ \\
\hline $36^{\text {th }}$ to $40^{\text {th }}$ floor & $\begin{array}{l}\text { Periphery column } \\
\text { Inner column }\end{array}$ & $\begin{array}{l}457 \times 457 \\
533 \times 533\end{array}$ & $\begin{array}{l}533 \times 533 \\
610 \times 610\end{array}$ & $\begin{array}{l}533 \times 533 \\
762 \times 762\end{array}$ & $\begin{array}{l}533 \times 533 \\
762 \times 762\end{array}$ \\
\hline Beam & $\begin{array}{l}\text { Periphery beam } \\
\text { Inner beam }\end{array}$ & $\begin{array}{l}254 \times 610 \\
305 \times 572 \\
\end{array}$ & $\begin{array}{l}203 \times 686 \\
203 \times 610 \\
\end{array}$ & $\begin{array}{l}381 \times 914 \\
305 \times 914 \\
\end{array}$ & $\begin{array}{l}381 \times 914 \\
381 \times 914 \\
\end{array}$ \\
\hline \multicolumn{2}{|c|}{ Slab } & 203 & 203 & 203 & 203 \\
\hline
\end{tabular}

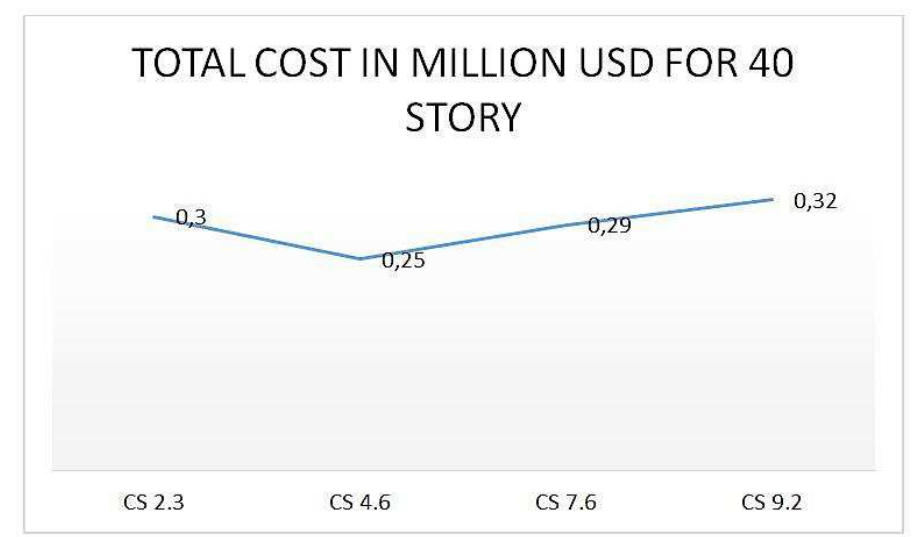

Fig. 8: Cost comparison for 40 story structure.

\subsection{Analysis for $\mathbf{5 0}$ story structure}

For 50 stories, all of the six framing models of the tube have been implemented here and drift was optimized by reducing cross-section sizes within the prescribed limit of code. The optimized results are shown in Fig. 9. 


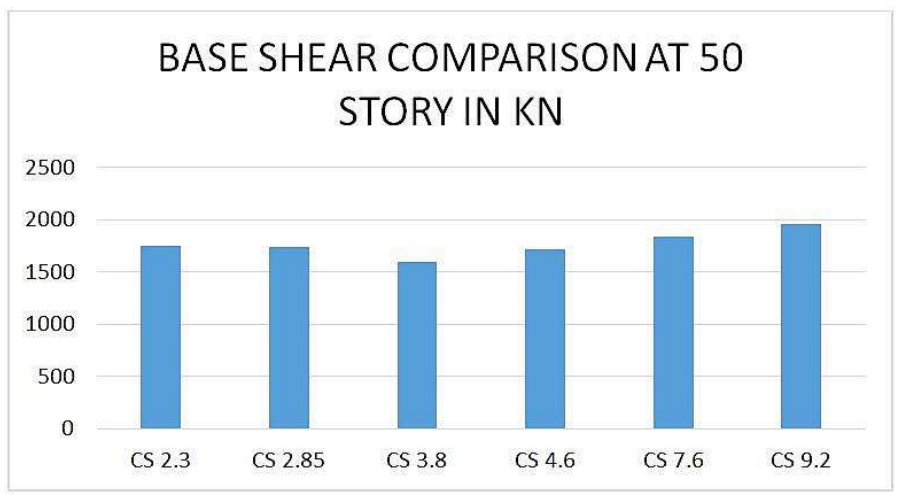

Fig. 9: Base shear results for 50 story building using different tube framings.

Table 4: Cross section details for all framing employed in 50 story structure (in $\mathrm{mm} \times \mathrm{mm}$ ).

\begin{tabular}{|c|c|c|c|c|c|c|c|}
\hline \multicolumn{2}{|c|}{ Element } & CS 2.3 & CS 2.85 & CS 3.8 & CS 4.6 & CS 7.6 & CS 9.2 \\
\hline $1^{\text {st }}$ to $5^{\text {th }}$ floor & $\begin{array}{l}\text { Periphery column } \\
\text { Inner column }\end{array}$ & $\begin{array}{l}1067 \times 1067 \\
1448 \times 1448 \\
\end{array}$ & $\begin{array}{l}1067 \times 1067 \\
1448 \times 448 \\
\end{array}$ & $\begin{array}{l}1067 \times 1067 \\
1524 \times 1524 \\
\end{array}$ & $\begin{array}{l}1219 \times 1219 \\
1524 \times 1524 \\
\end{array}$ & \begin{tabular}{|l|}
$1524 \times 1524$ \\
$1524 \times 1524$ \\
\end{tabular} & $\begin{array}{l}1524 \times 1524 \\
1829 \times 1829 \\
\end{array}$ \\
\hline $6^{\text {th }}$ to $10^{\text {th }}$ floor & $\begin{array}{l}\text { Periphery column } \\
\text { Inner column }\end{array}$ & $\begin{array}{c}914 \times 914 \\
1372 \times 372\end{array}$ & $\begin{array}{c}991 \times 991 \\
1372 \times 372 \\
\end{array}$ & $\begin{array}{c}991 \times 991 \\
1448 \times 1448\end{array}$ & $\begin{array}{l}1143 \times 1143 \\
1448 \times 1448\end{array}$ & $\begin{array}{l}1448 \times 1448 \\
1600 \times 1600\end{array}$ & $\begin{array}{l}1448 \times 1448 \\
1753 \times 1753 \\
\end{array}$ \\
\hline $11^{\text {th }}$ to $15^{\text {th }}$ floor & $\begin{array}{l}\text { Periphery column } \\
\text { Inner column }\end{array}$ & $\begin{array}{c}30 " \times 30 " \\
1295 \times 295\end{array}$ & $\begin{array}{c}914 \times 914 \\
1295 \times 295\end{array}$ & $\begin{array}{c}914 \times 914 \\
1372 \times 1372 \\
\end{array}$ & $\begin{array}{l}1067 \times 1067 \\
1372 \times 1372 \\
\end{array}$ & \begin{tabular}{|l|}
$1295 \times 1295$ \\
$1448 \times 1448$ \\
\end{tabular} & $\begin{array}{l}1295 \times 1295 \\
1676 \times 1676 \\
\end{array}$ \\
\hline $16^{\text {th }}$ to $20^{\text {th }}$ floor & $\begin{array}{l}\text { Periphery column } \\
\text { Inner column }\end{array}$ & $\begin{array}{c}686 \times 686 \\
1219 \times 219 \\
\end{array}$ & $\begin{array}{c}838 \times 838 \\
1219 \times 219 \\
\end{array}$ & \begin{tabular}{|c|}
$838 \times 838$ \\
$1295 \times 1295$ \\
\end{tabular} & $\begin{array}{c}991 \times 991 \\
1295 \times 1295 \\
\end{array}$ & \begin{tabular}{|l|}
$1219 \times 1219$ \\
$1372 \times 1372$ \\
\end{tabular} & $\begin{array}{l}1219 \times 1219 \\
1600 \times 1600 \\
\end{array}$ \\
\hline $21^{\text {st }}$ to $25^{\text {th }}$ floor & $\begin{array}{l}\text { Periphery column } \\
\text { Inner column }\end{array}$ & $\begin{array}{c}686 \times 686 \\
1067 \times 067\end{array}$ & $\begin{array}{l}686 \times 686 \\
991 \times 991\end{array}$ & $\begin{array}{c}762 \times 762 \\
1143 \times 1143\end{array}$ & $\begin{array}{c}914 \times 914 \\
1219 \times 1219\end{array}$ & $\begin{array}{l}1067 \times 1067 \\
1219 \times 1219\end{array}$ & $\begin{array}{l}1067 \times 1067 \\
1372 \times 1372 \\
\end{array}$ \\
\hline $26^{\text {th }}$ to $30^{\text {th }}$ floor & $\begin{array}{l}\text { Periphery column } \\
\text { Inner column }\end{array}$ & $\begin{array}{l}610 \times 610 \\
991 \times 991\end{array}$ & $\begin{array}{l}686 \times 686 \\
991 \times 991\end{array}$ & $\begin{array}{c}686 \times 686 \\
1067 \times 1067\end{array}$ & $\begin{array}{c}838 \times 838 \\
1143 \times 1143\end{array}$ & $\begin{array}{c}991 \times 991 \\
1143 \times 1143\end{array}$ & $\begin{array}{c}991 \times 991 \\
1219 \times 1219\end{array}$ \\
\hline $31^{\text {st }}$ to $35^{\text {th }}$ floor & $\begin{array}{l}\text { Periphery column } \\
\text { Inner column }\end{array}$ & $\begin{array}{l}610 \times 610 \\
914 \times 914\end{array}$ & $\begin{array}{l}610 \times 610 \\
914 \times 914\end{array}$ & $\begin{array}{l}610 \times 610 \\
914 \times 914\end{array}$ & $\begin{array}{c}762 \times 762 \\
1067 \times 1067\end{array}$ & \begin{tabular}{|c|}
$914 \times 914$ \\
$1067 \times 1067$
\end{tabular} & $\begin{array}{c}914 \times 914 \\
1143 \times 1143\end{array}$ \\
\hline $36^{\text {th }}$ to $40^{\text {th }}$ floor & $\begin{array}{l}\text { Periphery column } \\
\text { Inner column }\end{array}$ & $\begin{array}{l}533 \times 533 \\
838 \times 838\end{array}$ & $\begin{array}{l}533 \times 533 \\
838 \times 838\end{array}$ & $\begin{array}{l}533 \times 533 \\
838 \times 838\end{array}$ & $\begin{array}{l}686 \times 686 \\
991 \times 991\end{array}$ & \begin{tabular}{|l|}
$762 \times 762$ \\
$914 \times 914$ \\
\end{tabular} & $\begin{array}{l}762 \times 762 \\
991 \times 991\end{array}$ \\
\hline $41^{\text {st }}$ to $45^{\text {th }}$ floor & $\begin{array}{l}\text { Periphery column } \\
\text { Inner column }\end{array}$ & $\begin{array}{l}457 \times 457 \\
686 \times 686\end{array}$ & $\begin{array}{l}457 \times 457 \\
762 \times 762\end{array}$ & $\begin{array}{l}457 \times 457 \\
762 \times 762\end{array}$ & $\begin{array}{l}610 \times 610 \\
838 \times 838\end{array}$ & $\begin{array}{l}610 \times 610 \\
762 \times 762\end{array}$ & $\begin{array}{l}610 \times 610 \\
914 \times 914\end{array}$ \\
\hline $46^{\text {th }}$ to $50^{\text {th }}$ floor & $\begin{array}{l}\text { Periphery column } \\
\text { Inner column }\end{array}$ & $\begin{array}{l}457 \times 457 \\
610 \times 610\end{array}$ & $\begin{array}{l}457 \times 457 \\
610 \times 610\end{array}$ & $\begin{array}{l}457 \times 457 \\
610 \times 610\end{array}$ & $\begin{array}{l}533 \times 533 \\
686 \times 686\end{array}$ & $\begin{array}{l}533 \times 533 \\
610 \times 610\end{array}$ & $\begin{array}{l}533 \times 533 \\
762 \times 762\end{array}$ \\
\hline Beam & $\begin{array}{c}\text { Periphery beam } \\
\text { Inner beam }\end{array}$ & $\begin{array}{l}381 \times 610 \\
381 \times 610 \\
\end{array}$ & $\begin{array}{l}203 \times 762 \\
203 \times 457 \\
\end{array}$ & $\begin{array}{l}254 \times 762 \\
203 \times 533 \\
\end{array}$ & $\begin{array}{l}305 \times 838 \\
203 \times 533 \\
\end{array}$ & $\begin{array}{l}305 \times 1067 \\
305 \times 1067 \\
\end{array}$ & $\begin{array}{l}305 \times 1067 \\
305 \times 1067 \\
\end{array}$ \\
\hline \multicolumn{2}{|c|}{ Slab } & 203 & 203 & 203 & 203 & 203 & 203 \\
\hline
\end{tabular}

In 50 story structure all framing systems are well optimized and analysis shows that CS 3.8 is the most economical among all and it is well stiffer than other systems as shown in Fig. 10. The details of all optimized cross-sections are summarized in Table 4. The cost of the structural components has been calculated and shown in Fig. 11.

DRIFT COMPARISON FOR SEISMIC LOADING

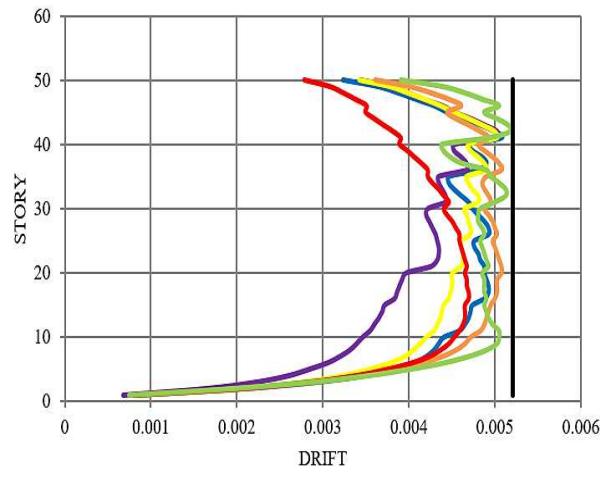

DRIFT COMPARISON FOR WIND LOADING

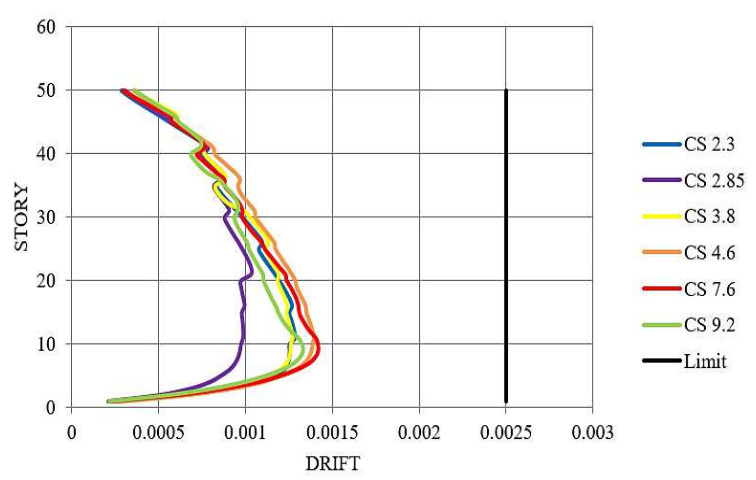

Fig. 10: Drifts comparison of the different tubular frame for 50 story structure. 


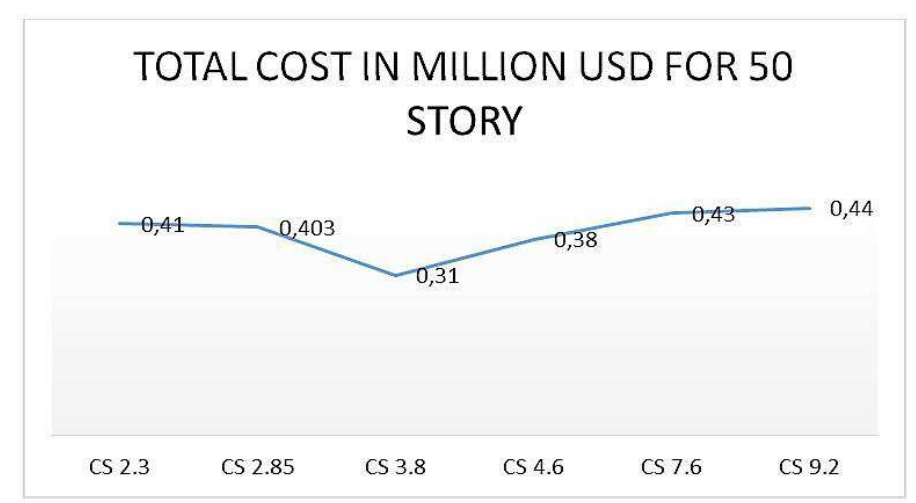

Fig. 11: Cost comparison for 50 story structure.

\section{Conclusions}

Based on the results, it can be concluded that for a square symmetrical planned building CS 4.6 system is most suitable up to 40 story structure as it is found to be well stiff and most economical so the spacing of columns at the periphery of the tube would be 4.6 while for structures more than 40 stories CS 3.8 system is recommended with the column spacing of 3.8 at the periphery of the tube. Further reduction in column spacing yields a higher cost and may be suitable for higher seismic zones but for moderate seismic zones, the above-discussed results are suggested.

Moreover, it can be concluded that as the spacing of the column tends to increase in the tube periphery, the cross-section sizes of the column become heavier and ultimately increase the cost of the project. The same observation is valid for the sizes of beams as well. Also, a more reduced spacing of columns less than $3.8 \mathrm{~m}$ yields more cost so a tube structure is suggested for buildings having 40 or more stories with the symmetrical plan. For an unsymmetrical plan, further research can be made with outriggers and shear walls with comparison to the tube.

\section{Acknowledgment}

Authors would like to acknowledge the support and facilities given by Sir Syed University of engineering and technology and also would like to thank the Engr. Mustajab of M/S. Arif \& Associates for providing technical guidelines and software skills throughout this research project.

\section{References}

[1] WEINGARDT, R. G.: Great Achievements, noble structural engineers. Fazlur Rahman Khan, The Einstein of structural engineering. Structure magazine, 2011, pp. 44-46.

[2] BEEDLE, L. S. - ALI, M. M. - ARMSTRONG, P. J.: The Skyscraper and the City: Design, Technology, and Innovation. Book 1 and 2, Lewiston, NY, USA, the Edwin Mellen Press, 2007.

[3] KHAN, F. R.: Evolution of Structural Systems for High-Rise Buildings in Steel and Concrete. Proceedings of the Regional Conference on Tall Buildings, Bratislava, Czechoslovakia, Sep. 17$19,1973$.

[4] ALI, M. M - MOON, K. S.: Advances in structural systems for tall buildings: Emerging developments for contemporary urban giants. Buildings, Vol. 8, Iss. 8, 2018, pp.104-137.

[5] KHEYRODDIN, A. - MASHHADIALI, N. - KHEYRODDIN, F.: Optimum design of tall tube-type building: An approach to structural height premium. International journal of Civil and Environmental Engineering, Vol. 12, Iss. 6, 2018, pp. 677-681.

[6] MOON, K. S.: Diagrid structure for complex-shaped tall buildings. Procedia Engineering, Vol. 14, 2011, pp. 1343-1350.

[7] GHASEMZHADEH, H. - SAMANI, H. R.: Estimating frequency of vibration for tubular tall buildings. $14^{\text {th }}$ ECEE, Ohrid, North Macedonia, 30 Aug. - 03 Sep. 2010.

[8] LEE, W. H.: Free Vibration Analysis for Tube-in-Tube Tall Buildings. Journal of Sound and Vibration, Vol. 303, 2007, pp. 287-304.

[9] LAVANYA, T. - SRIDHAR, S. R.: Dynamic analysis of tube-in-tube tall buildings. International research journal of engineering and technology, Vol. 4, Iss. 4, 2017, pp. 2357-2362.

[10] GHASEMI, H. A.: Optimal design of high-rise building bundled tube systems. Advances in Science \& Technology Research Journal, Vol. 10, Iss. 30, 2016, pp. 96-102. 
[11] PONNADA, M. R.: Effect of column spacing on G+5 RC moment resisting frame - A typical computer aided case study. International journal of $u$ - and e- service, Science and technology, Vol. 8, Iss. 4, 2015, pp. 85-102.

[12] LAKSHMI, G. S.: Influence of optimal column spacing for $G+11$ story RC moment resisting frame. International Journal of Civil Engineering \& Technology, Vol. 8, Iss. 1, 2017, pp. 397-408.

[13] ACl Committee 318, Building code requirements for structural concrete: (ACl 318-08); and commentary (ACl 318R-08). Farmington Hills, MI: American Concrete Institute, 2008.

[14] ASCE-7, Minimum design loads and associated criteria for buildings and other structures. ASCE/SEI standards 7-10, Reston, Virginia, American Society of Civil Engineers, 2010.

[15] UNIFORM BUILDING CODE (UBC-97), Structural Engineering Design Provisions. International Conference of Building Officials, Whittier, 1997, p. 492. 